\title{
Multiple Cropping for Raising Productivity and Farm Income of Small Farmers
}

\author{
Mina Nath Paudel \\ National Agriculture Genetic Resources Center, Khumaltar, Kathmandu \\ Correspondence: mnpaudel@gmail.com
}

Received September 2015, Revised August 2016; Accepted November 2016

Scientific Editors: Madav Joshi, Tek B. Gurung, Ananda P. Gautam

Copyright @ 2016 NARC. Permits unrestricted use, distribution and reproduction in any medium provided the original work is properly cited

\begin{abstract}
Multiple cropping is an agriculture system long adopted by marginalized small holder farmers especially in hills and mountains. This practice was a meant to enhance farm productivity when farming area is limited. Here, in this paper, a brief review on the benefits of multiple cropping is presented focusing on the practices adopted by marginalized farmers, in general. In multiple cropping, it is generally argued that the practice favors an efficient utilization of resources like air, water, light, space, and nutrients by companion crops in both temporal and spatial dimensions due to their differential growth habits and seasonality. Multiple cropping could be one of the viable alternatives to cope uncertainties and changes, where food and nutritional uncertainty looming large. The ultimate outcome of multiple cropping could be visualized in adverse or harsh environment for increase agriculture production, livelihood and income. Various food products are obtained through multiple cropping. Land equivalent ratio (LER), relative yield total (RYT) and income equivalent ratio (IER) can be increased with mixed/intercropping systems. Multiple cropping helps in getting more than one crop simultaneously, so even if the selling price of one commodity is less, the other might compensate. In the tropics, smallholder farms, which produce over $60 \%$ of the food resources of developing nations from intercropping of cereals with many crops mostly legumes, had been the field of much investigation because of synergistic effects of diversifying food production and household cash incomes in these systems. This clearly implies the importance of multiple cropping for small farmers who constitute majority in the developing countries.
\end{abstract}

Keywords: Food and nutritional security, marginal farmers, multiple cropping, livelihood, sustainability

\section{सारांश}

एक बालीको तुलनामा बहुबाली र मिश्रित बाली धेरै उपयोगी भएको यथार्थ अनुसन्धानबाट सिद्ध भएको छ,। मिश्रित बाली प्रणालीमा हवा, पानी, प्रकाश, स्थान र पोषक तत्व जस्ता श्रोतहरुको उपयोग राम्रोसँग भएको पाईएको छ। यस पद्धतिमा बिभिन्न होंचा तथा अग्ला बालीहरु एकै स्थानमा लगाउनाले प्राकृतिक श्रोतहरुको यथोचित सदुपयोग हुने अवस्था रहन्छ। खाद्यान्न अभाव रहने देशहरुमा मिश्रित बाली प्राणाली जलवायु परिवर्तन, भोकमरी र खाद्य असुरक्षा जस्ता समस्यालाई समाधान गर्ने भरपर्दो माध्यम हुनसक्छ। यस पद्धतिमा कार्बन संश्लेषण प्रभावकारी रुपमा हुनहहुँदा बाली उत्पादनमा अत्यधिक राम्रो नतिजा निस्कन्छ। बहुबाली र मिश्रित बाली पद्धतिमा खेती गर्न नसकिने जस्तो अवस्था भएका क्षेत्रहरुमा प्राप्त भएको उत्पादनबाट कृषकको जीवनयापन, रोजगारी, आयआर्जन र प्राकृतिक श्रोत साधनको व्यवस्थापनमा उलेख्य सुधार हुने पाइएको छ। यस प्रणालीमा खाद्यान्न उत्पादनमा बिबिधता हुनाले खानाका प्रकारमा समेत बिबिधतायुक्त खाना प्राप्त गर्ने अवसर उपलब्ध हुन्छ। लेन्ड एकुभालेण्ट रेसियो (Land Equivalent Ratio, LER), रिलेटिभ यिल्ड टोटल ( Relative Yield Total, RYT) र इन्कम एक्युभालेण्ट रेसिओ (Income Equivalent Ratio, IER) जस्ता सूचकहरुको यस प्रणालीमा राम्रो बढोत्तरी भएको पाईएको छ। साथै, मिश्रित बालीमा बजारीकरण समेत प्रभावकारी भएको पाईएको छ, किनकि एक बालीमात्र बजारीकरण गर्दा मूल्यमा ह्रास हुनसक्छ। तर, बहुबालीमा एक बालीले अर्को बालीको मूल्यमा सन्तुलन कायम गराउन सक्छ। यी माथिका फाईदा बहुबालीरमिश्रितबालीबाट हुनेहुँदा यसको प्रचार प्रसार राम्रोसँग हुन पई। उष्पप्रदेशीय क्षेत्रहरुमा खाद्यान्न बालीसँग कोशेबाली मिसाएर कुल उत्पादनको ६० प्रतिशतसम्म अन्तरबाली र मिश्रित बाली र बहुबाली पद्धतिबाट प्राप्त भएको अनुसन्धानबाट सिद्ध भएको छ। तसर्थ, यो बाली प्रणालीलाई विकासोन्मुख देशहरुका साना तथा सिमान्तकृत कृषकहरुलाई यसको महत्व दर्शाउनु जरुरी आवश्यक छ।

\section{INTRODUCTION}

Multiple cropping is defined as the intensification of cropping in time and space leading to growing two or more crops on the same field in a year (Andrews 1976, Joshi 2007, Degla et al 2016). In Nepal, subsistence farming under rainfed condition which is around 70\% of total cultivation is practiced since history. Multiple cropping is not a new form of agricultural technology, instead is an ancient means of intensive farming. Multiple cropping has been practiced in many parts of the world as a way to maximize land productivity in a small area in growing season by improving the intensity of land and labor use for better profit and stabilizing farm income (Joshi 2007). In this cropping pattern planting two or more crops on the same field is more common in tropical regions having more rainfall, higher temperatures, and longer growing seasons for continual crop production. The use of multi cropping systems is more prevalent in developing countries, in general. The history of multiple cropping is old; however, the concept has received very little attention from agricultural scientists. Recently, some interest has been generated very recently as one of the climate change adaptation strategies (Degla et al 2016).

There are calls for immediate attention to policy makers and agriculturalists to address food and nutritional security of burgeoning population of the $21^{\text {st }}$ century (Rezitus 2016). In one hand it has begun to observe a leveling off in yield increases brought about by "Green Revolution" (Conway 1979) and intensive use of agricultural inputs on large-scale use of single varieties developed by institutions under Consultative Groups on International Agriculture Research (CGIAR) and other research institutions. The other factor limiting production of crops under monoculture is energy especially oil crisis is of prime concern affecting livelihood of poor and marginal communities of Asia, Africa and Latin America (Rezitis 2016). Oil prices continue to increase and time has come to go for alternative ways to replace fossil fuel thereby renewable energy seems very need of the day although it will take to massively use of this energy to replace fossil fuel (Popp et al 2014). Consequently, cost of production of agriculture commodity has been increasing and 
increase cost of fertilizers, pesticides, fuel, farm equipment and irrigation facilities are almost out of reach of small farmers of the third world (Popp et al 2014). The ultimate impact of these factors could exert pressure on food and nutritional insecurity of already vulnerable groups of population such as children, pregnant/lactating women and elders who are in dire need of food for growth, maintenance and production. Hence, there is the need to consider other alternatives that might allow us to substitute innovative biological or agronomic practices and varieties for these high cost inputs. Multiple cropping offers one of the most important and promising of these alternatives. To document the importance of the multiple cropping system, the present briefly elucidate the benefits of smallholders based multiple cropping system.

\section{Multiple Cropping in Nepalese Farming Systems}

Nepal is a unique country from climatic and topographical point of view. Cropping patterns in Nepal are influenced by the altitude as illustrated in the Figure 1 (Sthapit 1983). As depicted in the Figure 1, in Tarai, farmers in the lower altitude grow as many as three crops a year per plot, provided there is irrigation; whereas in higher hill intensive cropping cannot be followed due to limitation of favorable temperature even in domain having year round irrigation facilities. In hills where temperature and irrigation are not limiting, crops can be grown as that of Tarai region. The number of months of frost-free growing period is also affected by the altitude. It can range from as many as twelve months in the Tarai to as little as six months in the mountain region. So the tarai, with a longer growing period and shorter crop duration, has a higher potential for food production through multiple cropping. This is not the case in the hills and the mountain region, where the crop growing period is shorter and it also takes a longer time for crops to mature. Therefore, multiple cropping in Nepal is governed by altitude, temperature, irrigation and other biophysical parameters (Chhetri 2011). A picture of integration of different multiple cropping systems encompassing crop, livestock, agroforestry, fodder and pasture including homestead manuring have been shown (Figure 1).

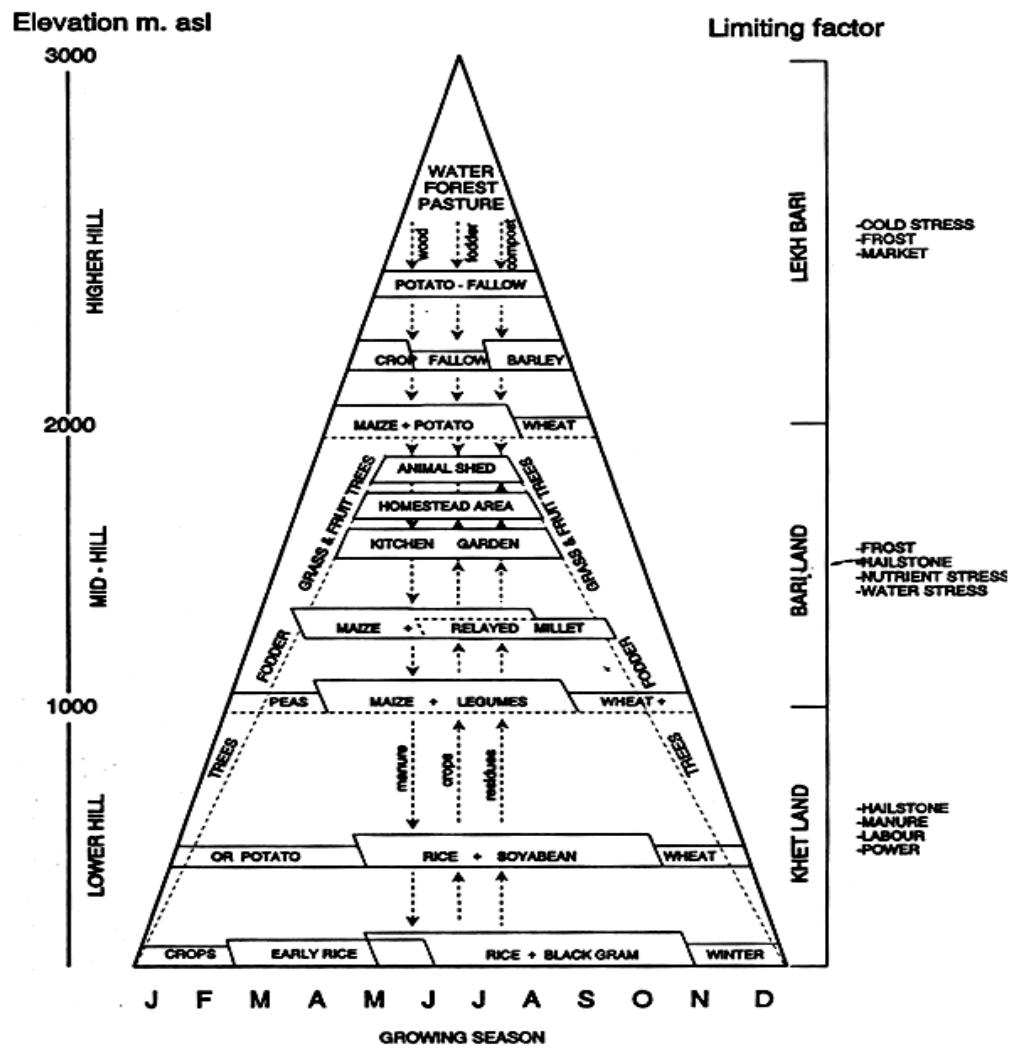

Figure 1. Schematic representation of cropping patterns as determined by altitude in Nepal (Sthapit 1983).

\section{Potential of Multiple Cropping Farming}

Many techniques are available to enhance food production such as increasing cropping intensity, practicing multiple cropping, and using inputs in balanced amounts with effective plant protection measures. However, among those multiple cropping is the most effective technique. Multiple cropping can be done in annual food crops, fodders, vegetables, fruit plants and perennial crops (Gliessman 1979, 1985, Degla et al 2016). Mixed cropping could enable the country to be self-sufficient in food production and export the surplus to generate revenue to finance the cost of other projects. Multiple cropping by definition makes effective use of inputs such as soil, water, fertilizer, land and labor, capital, the factors of production as a whole.

Among the multiple cropping, both row or seed inter cropping, relay cropping and mixed cropping (Aiyer 1942) are important types practiced with main crops such as cereal, legumes, fruits, vegetables, forage and fodder and many other crops of economic importance. 
In intercropping, minor crops are planted in between rows or mixing of seeds in certain proportion with major crops. For instance, the crops like maize, mustard, garlic, onion, potato, okra, coriander, fenugreek, melons (watermelon, muskmelon) can be successfully intercropped with sugarcane crop in between the rows of sugarcane when establishment of major crop takes some time and competition between main crop and inter crops is minimum. The crops in intercropping may have a different sowing and harvesting time as well.

Intercropping with sugarcane depends upon the season in which sugarcane is grown such as autumn or February planting. Accordingly other companion crops within the main crop could be grown as bonus crops. In orchard under tropics, inter crops such as legumes (soybean, beans, groundnut, mung and seasonal vegetables such as brinjal, lady's finger, cucurbits including squash could be grown whereas in subtropics and temperate region inter crops such as cole crops (cabbage, cauliflower, knoll-khol carrot, leaf mustard, turnip), radish, chayote, pea, kidney bean, parsley, onion, garlic, potato, and many locally available crops could be grown to provide healthy and nutritious food to the family, if not for commercial purpose. This will provide economic benefit to growers aside from controlling weeds in the orchards. In Tarai region of Nepal under wheat crop, intercropping of mustard, linseed, lentil, and gram can be grown during winter, whereas in hills pea is intercropped with wheat; and in high hills wheat and barley are inter cropped in mixing seed of these crops while planting. There are many types of multiple cropping practices in the world; however the potential ones are discussed herein.

\section{Crop Rotations}

Crop rotation or sequential cropping refers to the planting of one crop follows the harvesting of the preceding crop on the same parcel of land over time. Rice, maize, wheat, finger millet, potato and pulses are the major staple crop of Nepal. In 2012, area under these crops was; rice (1. 532 million ha), maize ( 0.871 million ha), wheat ( 0.765 million ha), finger millet $(0.278$ million ha), potato $(0.187$ million ha), and pulses (0.328 million ha) with respective productivity of $3.311 \mathrm{t} / \mathrm{ha}, 2.502 \mathrm{t} / \mathrm{ha}, 2.413 \mathrm{t} / \mathrm{ha}, 1.133 \mathrm{t} / \mathrm{ha}, 14.348 \mathrm{t} / \mathrm{ha}$, and 0.977 t/ha (MoAD 2012). Crop rotations are governed mainly by rice, maize and wheat based systems under irrigated and rainfed ecosystems for these crops are grown basically in irrigated and rainfed system although major portion (70\%) of area under cultivation falls under rainfed system which is dependent on south east monsoon that generally starts from the second week of June (June 10) and lasts up to the last week of the September (September 23). However, sometime the monsoon starts one week ahead of June and recess at the first week of October.

\section{Rice Based Cropping Patterns}

In Nepal, crop rotations under irrigated conditions of Tarai and river basin domains are rice-fallow-maize, rice-maize-fallow, rice-wheatfallow, rice- fallow-rice, rice-lentil-maize, rice/lentil-maize, rice-maize+cowpea, rice-maize/mung, rice-wheat/mung (Khadka 2010). Of these, crop rotation with legumes were found four times economically productive than those of cereal based rotations, thus inclusion of legumes in the cereal based cropping systems was found as cash enterprise in the system (Khadka 2010). Eighty percent of rice is planted in the normal season (June/July to October /November) as rainfed crop; around 10\% of the rice is planted in spring season (February/March to June/July), if irrigation facilities are available round the year. Double crop of rice followed by winter vegetable is taken in irrigated areas as intensive cropping. Upland rice in rice+maize patterns is grown as mixed crops in Siwalik, Churia, some inner Tarai and Tar (plain area in the river basin zone) areas. Legumes are important crops in Nepal grown in Tarai, hill and mountain due to vast diversity. Legumes provide valuable protein to humans and animals aside from enriching soil by trapping atmospheric nitrogen. Because of these reasons, legumes are incorporated with cereals in different agro-climatic domains for intercropping. In rice based cropping systems under Tarai, inner Tarai and river basin areas, the important cropping systems that include legumes (Yadav 2003, Joshi 2007) are rice/lentil-fallow, rice/lentil+ mustard, rice /lentil-maize, rice /lathyrus-maize, rice-rice-chickpea, rice-rice-lentil or lathyrus + linseed, rice-wheat or mustard-mung- bean, rice + pigeon pea (on bunds)-fallow. Cropping systems in the hills and lower valley where legumes are integral parts of systems include; rice +soybean (on bunds)-wheat, rice +black gram (on bunds)-wheat or barley, rice +rice-bean (on bunds)-wheat.

In the mid hills, rice is cultivated under irrigated or partially irrigated and without irrigation in upland condition. Shrestha et al (2012) showed that the prominent cropping patterns under irrigated condition were rice-mustard-maize and rice-wheat-maize that covers $50 \%$ areas, while under partially irrigated condition rice-wheat-maize was the important cropping pattern covering $95 \%$ area, while about $5 \%$ area was under rice-mustard-maize and rice+soybean-fallow in the partially irrigated condition of Bharat Pokhari, Kaski. In the same area under rainfed condition, the prominent cropping patterns were maize/finger millet-mustard (50\%) and maize-black gram-mustard $(25 \%)$. Cropping patterns generally keep on changing based on the land type, irrigation facility, soil fertility, market demand, availability of labor, opportunity cost and family choices for the crops etc. Now, cereal based cropping patterns have been slowly being replaced by vegetable based cropping pattern such as maize-finger millet-mustard (50\%) has been replaced with maize-tomato-mustard (50\%), maize-black gram-mustard (25\%) with maize-tomato-beans (15\%) and maize-soybean-fallow (15\%) replaced with maize-millet-mustard (30\%) under rainfed condition of road accessible mid hills in Nepal (Shrestha et al 2012). This could be because of cash incentives of vegetables compared to cereals. The intercropping of upland rice with peanut, cowpea and maize was introduced by 17,10 , and $8 \%$, respectively in marginal uplands in the Siwalik regions of Nepal (Shrestha et al 2012).

In mid and far western region of Nepal adjoining to Uttranchal and Uttrakhanda of India, there are different types of multiple cropping systems in rainfed upland conditions (Upreti 2002, Sangakkara et al 2012). These patterns of cropping systems are colorful encompassing amaranths and sorghum in the terrace risers followed by sesame+ upland rice+ maize in the main terrace. In other areas, finger millet + black gram in main terraces were surrounded by rice bean + red gram + sorghum in the terrace riser. These practices continued since the time immemorial in the regions. Growing of many crops in the form of mixed inter cropping gives farmers biological crop insurance in the sense, that if one crop fails other crops in the field compensate the loss of crops due to drought, insect pest infestation or any other natural calamities such as hail storm or floods. 
Vol. 2:37-45, December 2016

DOI: http://dx.doi.org/10.3126/jnarc.v2i0.16120

\section{Maize Based Cropping Patterns}

Maize in Nepal is mostly cultivated in rainfed condition in normal season (April/May to July/August) planting in mid and high hills, whereas early maize or spring maize (February/March to June/July) is planted as both irrigated (Tarai and river basin) and rainfed in the hills and mountain (Thapa 1995). Recently hybrid maize in some potential pocket of Tarai and road accessible areas of mid hills is planted as winter maize in irrigated condition (October/November to April/May). Important cropping patterns in inner Tarai and mid hills are maize-mung-fallow (rainfed), maize/finger millet-fallow (rainfed), and maize-millet-fallow (rainfed). In high hills, maize based cropping patterns of maize+ potato/ cole crops (cabbage, cauliflower, carrot, radish, turnip), and pea are becoming popular during February-September/October season (Paudel 2001). Inter cropping of maize and winter vegetables in the high hills (>1800 $\mathrm{m}$ ) has revolutionized productivity of the areas. Vegetable produced in the intercropping have been fulfilling demand of these vegetables in Tarai and nearby Indian markets during vegetable lean period of the rainy season (July-October).

Legumes are not only important in rice based system, but equally important in maize based cropping systems. Maize based cropping systems in uplands, where legumes are incorporated include maize-lentil + mustard, maize-chickpea + mustard, maize-chickpea + barley or wheat, maize + cowpeas- mustard or wheat, maize + soybean- mustard or wheat- pigeon pea- fallow, maize + pigeon pea-fallow, maize +cowpea-mustard or wheat, maize +beans-mustard or barley, maize/black gram-mustard or wheat (Yadav 2003).

Relay cropping of finger millet in maize is one of the most important cropping pattern in the hills; and of the total finger millet cultivation, over $85 \%$ is cultivated under relay inter cropping systems with maize (Subedi 1990). Suggesting that about $25 \%$ of total maize area accommodates finger millet as relay system in Nepal. Maize/finger millet relay system is old system. This system has helped maintain food and nutritional security from 500-1800 m since time old. In higher altitides of more than 1000 m, overlapping period of relay cropping becomes longer between maize and finger millet (Subedi 2002). Multiple cropping in the hills and mountain has been beneficial to rural poor by providing food from staggered harvest of crops grown under this system. Net return and land equivalent ratio (LER) for different legumes intercrops with maize revealed that the highest net return of Nepalese Rupees (NRs) 39374/ha followed by NRs 35166/ha were obtaine from 1:2 row of maize + groundnut and 1:1 row of maize + cowpea having LER of 1.73 and 1.66 (Table 1), respectively (Upreti 2002; Mishra 2002). These studies suggest that intercropping of different legumes with maize in the hill of Nepal is profitable (Pandeyet al 2002). From the same piece of land intercropping of legumes with maize could give 10- $73 \%$ more yield over mono-cropping of maize of either of the inter crops (Pandey et al 2002).

Prakash et al (1993) showed under maize+ finger millet (2:1 row) intercropping as an economic advantage of Indian Rupees (IRs) 3907 and LER of 1.3 over sole cropping of maize and finger millet (Table 1). These studies confirm that intercropping of either legumes or finger millet with maize is profitable, however, inter cropping of maize with legumes is more profitable and sustainable than with finger millet. In Srilanka, Sangakkara et al (2012) reported that inter cropping of maize with bean, cassava, sweet potato and tomato were evaluated for LER, yield and agronomic attributes. It was found that bean, tomato, and sweet potato intercropped with maize had LER values greater than unity, while that of cassava with maize was lower than 1 (Table 1). Yield advantage of corn from strip inter cropping on a per plant basis with higher plant population of 966,000 plants/ha was $63 \%$ for the $2: 4$ corn: mung bean spatial arrangement that gave the best LER value of 1.39 (Joshi 1985).

Table 1. Land equivalent ration (LER) and net return of different inter crops in Nepal and India

\begin{tabular}{|c|c|c|c|c|}
\hline $\mathbf{S N}$ & Crop combination & Net return (NRs/ha)* & LER & Reference \\
\hline 1. & Maize sole $(75 \times 25 \mathrm{~cm})$ & 27038 & & Mishra 2002 \\
\hline 2. & Maize+ soybean (1:1 row) & 34037 & 1.42 & \\
\hline 3. & Maize+ cowpea (1:1 row) & 40575 & 1.62 & \\
\hline 4. & Maize+ Jare bodi (1:1 row) & 30752 & 1.55 & \\
\hline 5. & Maize sole $100 \times 25 \mathrm{~cm}$ & 18467 & & \\
\hline 6. & Maize+ soybean (1:1 row) & 29147 & 1.45 & \\
\hline 7. & Maize+ cowpea (1:1 row) & 35863 & 1.66 & \\
\hline 8. & Maize+ Jare bodi (1:1 row) & 27032 & 1.59 & \\
\hline 9. & Maize +soybean (1:1 row) & 19822 & 1.32 & Upreti 2002 \\
\hline 10. & Maize + soybean (1:2 row) & 11921 & 1.26 & \\
\hline 11. & Maize + black gram (1:1 row) & 17384 & 1.5 & \\
\hline 12. & Maize + black gram (1:2 row) & 14096 & 1.57 & \\
\hline 13. & Maize + groundnut (1:21row) & 31674 & 1.47 & \\
\hline 14. & Maize + groundnut (1:2 row) & 39374 & 1.73 & \\
\hline \multicolumn{5}{|c|}{ Net return (IRs/ha)** } \\
\hline 15. & Maize sole & 3362 & 1.0 & Prakash et al 1993 \\
\hline 16. & Finger millet sole & 1000 & 1.0 & \\
\hline 17. & Maize + finger millet ( $2: 1$ row $)$ & 3907 & 1.3 & \\
\hline 18. & Maize + finger millet ( $2: 6$ row) & 2189 & $1: 1$ & \\
\hline 19. & Maize+ bean (pods) & & 1.43 & Sangakkara et al 2012 \\
\hline 20. & Maize+ cassava & & 0.98 & \\
\hline 21. & Maize+ sweet potato & & 1.36 & \\
\hline 22. & Maize+ tomato & & 1.38 & \\
\hline
\end{tabular}

* Based on Nepalese Rupees (NRs), ** Based on Indian Rupees (IRs) 


\section{Inter Cropping With Legumes}

The morphological and physiological differences among intercrop components result in their ability to occupy different niches (Keating and Carberry 1993). Thus, environmental resources could be more efficiently utilized and converted to biomass by mixed stands of crops than by pure stands. Differences in vertical arrangement of foliage and canopy architecture of intercrop components, may lead to more PAR (photo-synthetically active radiation) interception by intercropping compared with sole crops (Keating and Carberry 1993). More PAR interception by different intercropping systems has been reported (Chand 1997, Midmore et al 1988). PAR interception seems to play a relatively important role in determining total intercrop productivity. High light interception by intercrops caused higher shading and, therefore, lowers soil temperature.

Intercropping of legumes with forage is done to improve quality of forage and maintain productivity of land. Mixtures of cereals and legumes are used extensively for forage production. A study by Eskandari and Ghanbari (2009) revealed that maize (Zea mays) and cowpea (Vigna sinensis) monocultures as well as their mixture in three planting patterns (alternate-row intercrop, within-row intercrop, and mixed intercrop) intercropping systems had a significant effect on forage dry matter yield. The study also found that intercropping of maize and legumes in the systems had a higher consumption of PAR (97-98\% for inter crops and 62-71\% for sole crops) and soil temperature maintenance $\left(26-27{ }^{0} \mathrm{C}\right.$ for inter crops and $28-29{ }^{0} \mathrm{C}$ for sole crops) 70 days after planting indicating higher utilization of environmental resources in inter cropping (Eskandari and Ghanbari 2009). Similarly, maize forage quality in terms of crude protein (101-102 g/kg for inter crops and 76-100 g/kg dry matter) was improved by intercropping. Increase in crude protein in the intercrops could be due to symbiotic effect of $\mathrm{N}$ fixing by legumes which benefited companion crop of maize. An inter cropping of legumes on mango orchard after two years of establishment in central Tarai Nepal revealed that of the five legumes inter crops in the orchard, rajmah (kidney bean) and pole bean gave higher net benefit of NRs 127200 and NRs 53080.00, respectively (Table 2) from the sale of green pod of legumes (Shrestha et al 2013).

Table 2. Economic benefit from five legumes inter cropped in mango orchard in Nepal (Shrestha et al 2013)

\begin{tabular}{lcc}
\hline Crop (green pod) & Net benefit (NRs/ha) & Benefit cost ratio \\
\hline Rajmah & 127200.00 & 3.03 \\
Pea & 39525.00 & 0.88 \\
Broad bean & 7010.00 & 0.18 \\
Pole bean & 53080.00 & 1.06 \\
Cow pea & 2720.00 & 0.05 \\
\hline
\end{tabular}

\section{Relay Cropping}

Relay cropping or relay inter cropping entails growing two crops in the same place on the same parcel of land at least for a part of the season where intercropping of the second crop into the first crop is done before the harvest of the first crop. In Nepal with small land holding more yields is expected. Therefore, it is important to go for relay cropping for enhancing per unit productivity of the land from the same small parcel. MoAD (2012) revealed average size of land holding ( 0.8 ha) with average parcel size of 0.24 ha. Relay cropping could be viable alternatives for increasing crop productivity in such small and fragmented land systems of small parcels in Nepal. This explains the importance of multiple cropping to explore temporal and spatial arrangements of crops in small piece of land to sustain food and nutritional availability of increasing population. This also holds true in other countries of the world, where resources are becoming limited and scarce to sustain demand of food, feed, fiber, medicine and energy need of humans and animals especially in developing countries where population growth surpasses GDP growth.

Different forms of multiple cropping could answer increase of production in limited area and short span of time. The most important inter cropping is relay cropping of finger millet (Elusiana coracana L.) under maize (Zea mays L.) in mid hills of Nepal (Paudel et al 2001). From agronomic point of view, relay cropping of maize/finger millet seems nutrient exhaustive both crops being cereal and having same root systems. However, this practice seems very sustainable in marginal to semi fertile area of rainfed systems which could be partly explained that both being $\mathrm{C} 4$ crops. This is a unique system in which maize/ finger millet, both being cereal for long run calls for an in-depth study encompassing morpho-physiology, nutrient mining and plant protection in the system.

\section{Agroforestry}

Agroforestry is basically a land use strategy practiced by Nepalese farmers since time immemorial especially in hills and mountains farming that integrates perennial trees special of fodder and economic values with crop-livestock integrating systems under a common management practice. In other way, agroforestry is known as integration of trees into farming systems (Brady and Weil 2013). Agroforestry system that integrates fast growing, $\mathrm{N}$-fixing woody species into small scale farming systems show great promise in enhancing by supplying and cycling of plant nutrients in soil-plant system. It also increases plant productivity and soil quality. The fast growing trees during fallow period after the food crops have been harvested is another source of Nitrogen for the production system in sub humid areas. In such cases, $\mathrm{N}$-fixation rates are equivalent to those provided by leguminous forages in developed countries (Brady and Weil 2013). In Nepal, agroforestry is very popular farming where integration of tree, fodder, crop and animals are the integral part of farming in the hills and mountain even though this practice is common in other parts of the country as well.

\section{Alley Cropping}

Alley cropping is an agroforestry system that involves growing food crops in alleys, the border of which are formed by fast growing trees or shrubs, usually legumes. The hedge rows are pruned regularly to prevent shading of the food crops and pruning are used as mulch or/and fed to animals in Nepal where livestock is an integral part of farming systems. Many types of fodder trees are grown in the 
alley of mountain region of Nepal. Alley cropping with respect to runoff and soil erosion losses has immense benefits (Table 3). In areas, with ample rainfall and moderately fertile soil, alley cropping systems have proven to be successful. The soil is protected from excess erosion and soil quality is improved. But in other, quite infertile sub humid to semiarid areas, the hedge species compete with the food crops for nutrients and moisture and yield suffers (Brady and Weil 2013). Thus, alley cropping may be beneficial in specific cases.

Table 3. Ally cropping with legume tree as hedge row on runoff and soil erosion losses in Nigeria (Lal 1989)

\begin{tabular}{lcccc}
\hline \multirow{2}{*}{ System } & \multicolumn{2}{c}{ Runoff, \% of rainfall } & \multicolumn{2}{c}{ Soil erosion, Mg/ha } \\
\cline { 2 - 5 } & Corn & Cowpea & Corn & Cowpea \\
\hline Plow- till, no hedge rows & 17.0 & 4.3 & 4.3 & 0.63 \\
No -till, no hedge rows & 1.3 & 0.8 & 0.1 & 0.03 \\
Leucaena hedge rows & 4.9 & 1.1 & 0.6 & 0.13 \\
Gliricidia hedge rows & 4.3 & 0.7 & 0.6 & 0.07 \\
\hline
\end{tabular}

\section{Fruit-Cum-Fodder-Cum-Crops-Cum-Animal Production Systems}

Space available between the fruit tree (citrus: mandarin orange, sweet orange/naval orange, sour lemon), peach, plum, pear, banana, jack fruit, apple, guava) and fodder tree Badahar (Artocarpus lakoocha), Tanki (Bauhinia purpurea), Kalo Chuletro (Brassiopsis glomerulata), Bangekath (Populus ciliate), Koiralo (Bauhinia variegata), Kabro, Pakhuri, Dumri (Ficus spp), Kutmiro (Litsea monopetala), Dudhilo (Ficus nimarolis) and many locally available fruits and fodder trees. Inter cropping of maize, millets (mainly finger millet and foxtail millet) and many fodder crops such as Napier, Stylo, Digitaria, vetch, different legumes (cow pea, rice bean, green gram) can be utilized even in slopes and terrace riser of hills and mountains of Nepal. Lopping from the fodder trees are fed to the animals (cattle, buffalo, sheep and goat) which are integral part of farming in hills and mountain. Timber from fodder and fruit trees are used as fire wood and sometime local construction of sheds, thatches and even housing and manure from the animals are mostly used for the home garden and food crop of rice, maize, millet, potato and wheat in the region. Multiple cropping is especially important for fodder crops where it can provide enormous quantities of feedstuff for supporting sustainable livestock production. Thus, integration of fruit, fodder, animal and crops in the system is one of the most important subsystems of multiple cropping in hills and mountain of Nepal. Such sustainable systems of intensive farming exist since the dawn of civilization in the hills and mountain of the Himalaya region.

\section{Multiple Cropping with Respect to Irrigation Systems}

Multiple cropped lands can be broadly grouped into lowlands, irrigated uplands and rainfed uplands. In lowlands, rice based cropping systems predominate and number of crops per year and the crops that follow or precede rice depends on the periods of water availability and degree of control of water. When irrigation or rainfall is available around 8-9 months, double crop of rice or even triple crop of rice (www.agriinfo.in) with modern varieties with photo insensitive nature are possible to grow. In countries of tropics such as the Philippines, Thailand, Indonesia and many in ASEAN (Association of Southeast Asian Nations) and SAARC (South Asian Association for Regional Cooperation) region, the system of rice-rice-rice and rice-rice-upland crop mostly common. When this period limited to 67 months, upland crops-rice-uplands crops are generally taken as appropriate cropping patterns. In upland condition of Nepal, intercropping of rice with maize in rice+ maize system is planted before the onset of monsoon (February/March).

In rainfed uplands, cropping system is predominantly governed by intercropping during rainy season as maize+ pigeon pea in Tarai, Tar and mid hills of Nepal. Inter cropping of upland rice with maize in rice+ maize system in mid hills and parts of northern India is a common cropping pattern. Under upland system in Nepal, rice is cultivated in about $9 \%$ area of the total rice cultivation of 1.5 million ha. Of total area under upland rice, rice+ maize occupies about 25-30\% area. In rain fed condition, maize based cropping systems predominate in Nepal and maize relayed with finger millet or maize sequential with finger millet is the important cropping systems in mid hills of Nepal under maize based cropping system.

\section{Multiple Cropping with Respect to Soil Improvement}

Multiple cropping could also help in maintaining soil fertility provided suitable crops such as legumes are included in the cropping system. For example, intercropping of legumes could increase the process of nitrogen fixation and enhance the nutrient status of the soil. An important aspect of multiple cropping is the utilization of nutrients more efficiently as the crops growing on the same piece of land simultaneously would have different nutritional requirements. Intercropping controls soil erosion by preventing rain drops from hitting the bare soil. In maize + cowpea intercropping, cowpea acts as best cover crop and reduced soil erosion (Kariaga 2004). It was reported that taller crops act as wind barrier for short crops (Reddy and Reddi2007). There are studies that inter cropping are beneficial to conserve soil and it also improves soil condition in many ways. In brinjal+ groundnut intercropping, pod weight of brinjal in monocropping was low due to absence of intercrop which leads to high water evaporation in soil surface (Prashaanth et al 2009).

Complex diverse crop mixes, maintain or increase soil microbial diversity which is an indicator of good soil health. Altieri (1999) reported one gram of soil may contain over 1000 fungal hyphae and up to a million or more individual bacterial colonies which could help maintain soil health. Cover crop mixtures can provide a wide variety of plant types resulting in diverse easily decomposable residues with diverse root systems to support the soil biota. 


\section{Multiple Cropping with Respect to Plant Protection}

Mixed crops and cover crops can have varying effects on soil pathogens some positive and some negative (Altieri 1999). Brassica species suppress plant parasitic nematodes and soil borne diseases such as Pythium species by producing glucosinolate containing residues. Sudan grass is known for suppression of root-knot nematode (Meloidogyne hapla) in lettuce production, this may be caused by the release of cyanogenic compounds during decomposition of the Sudan grass residue (www.hort.cornell.edu/expo/proceedings/2012/). Legumes crops may support populations of lesion nematodes (Pratylenchus spp). There are instances that some repellent inter crops grown under sugarcane or fruit orchard as coriander, onion, garlic and fenugreek repel insect pests of the crops thereby increasing pollinators in the field have been reported. This is one of the tools of IPM in sustainable agriculture. Weed control by cover crops is caused by direct competition with weeds, the use of their residue as mulches and in some cases allelopathy; thereby eliminating, or reducing the rate, application number, or types of herbicides needed. In allelopathy, production of biochemicals under multiple cropping has deleterious effects on the growth and survival of other plants. The use of complex cover crop mixes may take advantage of the allelopathic suppression of weeds. Herbicide treatment and general weed suppression ability is generally higher in the mixed stands, as these crops have mostly higher plant densities than single stands (Fritz and Heimler2006).

Small scale farmers could double their productivity and cut costs by turning their plots into thriving ecosystems for instance, by using duck and fish in flooded rice fields to control pests and weeds and to nourish the plants with their droppings. Fish and duck can provide protein supplement in farmer's diet and even can increase the land productivity. In return the duck and fish can control some of rice pest and weeds from the rice field (Mukerjee 2013). Ecological agriculture (http://eap.mcgill.ca/General/eap_ind.htm) has cited many social and economic advantages of multiple cropping; dependence on only crop is avoided, less need to import energy, and wildlife is favored. Gliessman (1985) illustrated a series of advantages and disadvantages of multiple cropping for lesser developed countries on the basis of biological, physical, social and economic factors, accordingly, opportunities and limitations of multiple cropping.

Studies have shown that multiple cropping has number of advantages over mono-cropping. These include biological, physical, social and economic advantages for mobilizing resources in a sustainable manner in general and particular to small and marginal farmers. In multiple cropping, better use of vertical space and time, efficient capture of solar energy and nutrients are utilized judiciously. It is a low input sustainable farming encompassing integrated farming system with respect to crop management, insect pest control, and efficient utilization of temporal and spatial relations, and crop mixtures better permit the functioning of complex mutualisms and beneficial interactions between organisms. Also, the multiple cropping might be useful in reducing hunger and food security to ever burgeoning population of developing countries of Asia, Latin America, and Africa.

\section{Way Forward of the Multiple Cropping}

Despite the pros and cons of multiple cropping, there are enough evidences that multiple cropping is beneficial over mono or sole cropping. Sole crops might be fully damaged by drought, floods, hailstorms, hurricanes and epidemics. As a result famers will lose the whole crop and investment, and this will be disastrous for poor farmers. However, multiple cropping provides insurance against crop failures reduces pest and diseases incidence and provides additional yield advantage from the intercrops as bonus yield. Legumes used as mixed/intercrops will provide synergistic effect due to fixation of atmospheric nitrogen and thus improving soil physical property and fertility conditions. There will be efficient utilization of resources like air, water, light, space, and nutrients by the companion crops in both temporal and spatial dimensions due to their differential growth habits.

To further dig out in-depth importance and understandings of multiple cropping, research efforts should be focused on improving the existing mixed cropping system with a view to improving it in a sustainable way in terms of yield and conservation of the natural resource base (Jolloh 2010). Multidisciplinary research teams involving social and natural scientists together with farmers and extension agents should look at the entire system and not individual crops.

It is absolutely essential that in all of these interventions, small farmer must be the focus of study due to vagaries of climate change and uncertainty of agriculture in the third world where small and marginal farmers are affected adversely. Multiple cropping could be one of the viable alternatives to cope up these uncertainties and change in climate. Because farmers of the developing country particularly Asia, Africa and Latin America where there is food and nutritional uncertainty looming large. It is also necessary to empower farmers so that they can participate as equal partners in development. It is vital that farmers are able to articulate their views and needs in a coordinated manner for the purpose of self-organization as well as for the purpose to influence decision makers and for making effective alliances.

There is a need to create awareness about the importance and usefulness of multiple cropping over mono or sole cropping. This can be done by involving active participation of both public and private institutions including farmers' organization in local, regional and global level. In the process of new technology generation and application, including its legal framework such as patent rights and access to genetic resources, care must be taken by the governments to discuss with farmers' representative organizations, the consequences for farmers both in the short and long term (King 1999).

Because of creation of different canopy strata due to multiple cropping there will be facilitation of air mixing in the field that results availability of increased photosynthetically active radiation (PAR) to crops in the system which will have enhanced photosynthetic activity, hence synergic effect on production. Land equivalent ratio (LER), relative yield total (RYT) and income equivalent ratio (IER) can be increased with mixed/intercropping systems. Multiple cropping is also important from marketing point of view. As we are getting more than one crop simultaneously so even if the selling price of one commodity is less in the market, the other might compensate. In the tropics, smallholder farms, which produce over $60 \%$ of the food resources of the developing nations from intercropping of cereals mostly legumes is the field of well-studied areas, because of synergistic effects of diversifying food production 
Vol. 2:37-45, December 2016

DOI: http://dx.doi.org/10.3126/jnarc.v2i0.16120

and household cash incomes in these systems (Rao and Mathuva 2000, Kimaro et al 2009). This clearly implies the importance of multiple cropping for small farmers who constitute majority in the developing countries where they continue to play an important role in maintaining sustainability of the multiple cropping systems without jeopardizing environmental resources.

\section{ACKNOWLEDGEMENT}

Thanks to Nepal Agricultural Research Council for support.

\section{REFERENCES}

Aiyer A K. 1942. Mixed cropping in India. Indian J. Agr. Sci., 19:439.

Altieri M A. 1999. The ecological role of biodiversity in agro ecosystems. Agriculture Ecosystems and Environment, 74:19-31.

Andrews D J and Kassam A H. 1976. The importance of multiple cropping in increasing world food supplies. In: Papendick et al. Multiple Cropping, ASA Special Publ. No. 27:1.

Brady N C and R C Weil. 2013. The Nature and Properties of Soils, Agroforestry systems as Alternate to Slash-and-Burn. Revised $14^{\text {th }}$ edition, second impression, published by Dorling Kendersley, India Pvt. Ltd. New Delhi, India, Pp 974.

Chand S P. 1997. Effect of time planting of traditional potato varieties on yield of intercropped potato-maize in the hills of Nepal. PhD thesis. Wye College, University of London.

Chhetri N B. 2011. Climate sensitive measures of agricultural intensification: Case of Nepal. Applied Geography, 31:808-818.

Conway G R. 1979. Ecology in Agriculture, text of a seminar prepared for the Indian Agricultural Research Institute, Pusa as cited by S. R., Gliessman. In: Multiple Cropping Systems: A Basis for Developing an Alternative Agriculture, Environmental Studies University of California.

Degla P K, S A Adekambi, P Adanhoussode. 2016. Drivers of Multiple Cropping-Systems as Adaptive Strategy to Climate Econometric Methods, International Journal of Energy Economics and Policy, 2015, 5(3), 851-868.

Eskandari H and A Ghanbari. 2009. Intercropping of maize (Zea mays) and cowpea (Vignasinensis) as whole-crop forage: effect of different planting pattern on total dry matter production and maize forage quality. Not. Bot. Hort. Agrobot. Cluj, 37:2. 152-155.

Fritz M and F Heimler. 2006. Towards risk limitation and higher biomass quality: is mixed cropping an advisable strategy in energy crop production? http://www.hort.cornell.edu/expo/proceedings/2012/

Gliessman S R. 1979. Multiple Cropping Systems: A Basis for Developing an Alternative Agriculture, Environmental Studies, University of California.

Gliessman S R. 1985. Multiple cropping systems: A basis for developing an alternative agriculture. Office of Technology Assessment (ed.). Innovative Technologies for Lesser Developed Countries. Government Printing Office, Washington, Pp 69-86.

Jolloh A. 2010. Promoting appropriate intercropping technologies for sustainable agricultural production in Africa: A farmer centered approach, Institute of Agricultural Research, PMB 540, Freetown, Sierra Leone, http://www.codesria.org/IMG/pdf/Jalloh.pdf.

Joshi M. 2007. Multiple cropping systems. Agronomy Division, Khumaltar, NARC Pp-12.

Joshi M. 1985. Optimal spatial arrangement and population level in corn and mungbean strip inter cropping . MS thesis submitted to UPLB, the Philippines.

Kariaga B M. 2004. Intercropping maize with cowpeas and beans for soil and water management in western Kenya. Proceedings of the $13^{\text {th }}$ International Soil Conservation Organization Conference, July 2004, Conserving Soil and Water for Society, Brisbane, Pp: 1-5.

Keatin B and P Carberry. 1993. Resource capture and use in intercropping: Solar radiation. Field Crops Research. 34: $273-301$.

Khadka R. 2010. Sunkoshi/ Tama Koshi Kinarka Phantama Dal Bali Utpadan Prabidhi EkJhalak (Nepali version). Nepal Krishi Anusandhan Parishad, Bahya Anusandhan Mahasakha, Khumaltar, Lalitpur, Pp- 47.

Kimaro A A, V R Timmer, S A O Chamshama, Y N Ngaga, DA Kimaro. 2009. Competition between maize and pigeon pea in semi-arid Tanzania: Effect on yields and nutrition of crops. AgricEcosys Environ, 134: 115-125.

King D. 1999. Farmer-centered strategies for food security. Sustainable agriculture solutions: the action report of the sustainable agriculture initiative. Novello Press Ltd, London. 318 pp as cited by Jolloh A. 2010. In: Promoting appropriate intercropping technologies for sustainable agricultural production in Africa: A farmer centered approach, Institute of Agricultural Research, PMB 540, Freetown, Sierra Leone.

Lal R. 1989.Agroforestry systems and soil surface management of tropical alfisol: II: Water runoff, erosion and nutrient loss. Agroforestry Systems, 8:97-111.

Midmore D J, J Raco and D Berrios. 1988. Potato in hot tropics. IV. Intercropping with maize and the influence of shade on potato microenvironment and crop growth. Field Crops Research. 18:141-157.

Mishra M. 2002. Maize inter cropped with legumes in bariland under rainfed condition in the eastern hill of Nepal. In: N P Rajbhandari, J K Ransom, K Adhikari and A F E Palmer (eds.). 2002. Sustainable maize production systems for Nepal: Proceedings of a maize symposium held in December 3-5, 2001, Kathmandu, Nepal, NARC and CIMMYT.

MoAC. 2011. Statistical information on Nepalese agriculture. Agribusiness and Statistics Division, (Ministry of Agriculture and Cooperative, Kathmandu, Nepal.

MoAD. 2012. Selected indicators of Nepalese agriculture and population. Agribusiness and Statistics Division, Ministry of Agricultural Development, Kathmandu, Nepal.

Mukherjee M. 2013.The imperial roots of hunger. Himal South Asian, farms, feast, famines, Vol. 26, No 2: 12-25.

Pandey A K, N N Singh and H S Gupta. 2002. Maize based cropping systems in the hills of India. In: N P Rajbhandari, J K Ransom, K Adhikari and A F E Palmer (eds.) Sustainable maize production systems for Nepal: Proceedings of a maize symposium held on December 3-5, 2001, Kathmandu, Nepal, NARC and CIMMYT.

Paudel M N. 2001. Findings of participatory rural appraisal survey conducted in the high hills of Dhankuta, Dolkha, Myagdi and Dailekh districts during 1999/2000 (2056/57). ARSP Working paper No 255, ISSN 1021-5034.

Popp J, Z Lakner, M Harangi-Rákos, M Fári (2014) The effect of bioenergy expansion: Food, energy, and environment, Renewable and Sustainable Energy Reviews, 32: 559-578. 
Prakash V, V K Bhatnagar and K D Korane.1993. Improved cropping sequence for mid hills region of North-West Himalaya. Indian Journal of hill farming. 6 (1):79-84.

Prashaanth R, T H Seran, S Sivachandiran and I Brintha. 2009. Agronomic evaluation of brinjal (Solanummelongena L.) and groundnut (Arachishypogaea L.) intercropping system. J. GampahaWickramarachchi Ayurveda Inst., 4: 37-42.

Rao M R, Mathuva M N. 2000. Legumes for improving maize yields and income in semi-arid Kenya. Agrioc Ecosys Environ, 78: $123-137$.

Reddy T Y, G H S Reddi. 2007. Principles of Agronomy. Kalyani Publishers, India, Pp: 468-489.

Rezitis A N. 2016. Empirical Analysis of Agricultural Commodity Prices, Crude Oil Prices and US Dollar Exchange Rates using Panel Data

Sangakkara R, S Bandaranayake, U Attanayake, P Stamp. 2012. Impact of associated intercrops on growth and yield of maize (Zea. mays L) in major seasons of south Asia. Maydica electronic publication, 57: 6-10.

Shrestha H K, H B Gurung, D Gauchan, S Pandey, R B Yadav and P R Shakya 2012 Adoption of rice-based technologies in marginal uplands in Siwalik. Proceedings of the $3^{\text {rd }}$ SAAS-N convention 27-29 August 2008,Lalitpur, Jointly organized by Society of Agricultural Scientists, Nepal (SAS-N) and Nepal Agricultural Research Council (NARC), Pp 448.

Shrestha S L, K P Bhurer and R L Sah 2013. Inter cropping of winter legumes in mango orchard for economic yield and fertility maintenance in central Terai. Proceedings of $28^{\text {th }}$ National Winter crops Workshop, 9-10 March, 2011. Nepal Agricultural Research Council, Kathmandu, Pp 402.

Sthapit B R. 1983. Soybean production in the hills of Nepal. MSc thesis, Reading University, UK

Subedi K D. 2002. Maize and finger millet relay inter cropping system in the hills of Nepal: Issues for sustainability. In: N P Rajbhandari, J K Ransom, K Adhikari and AFE Palmer (eds.). 2002. Sustainable maize production systems for Nepal: Proceedings of a maize symposium haled, December 3-5, 2001, Kathmandu, Nepal, NARC and CIMMYT.

Subedi K D. 1990. Study of maize and finger millet relay inter cropping systems in the hills of Nepal: measures for production maximization. M. Sc. Thesis Submitted to the University of the Reading, U.K.

Thapa G B. 1995. Projections and policy implications of food supply and demand in Nepal to the year 2020. Research Report Series No. 30, Winrock International Policy Analysis in Agriculture and Related Resource Management, Kathmandu, Nepal: APROSC.

Upreti R P. 2002. Inter cropping study on maize with different legumes under hill condition. In: N P Rajbhandari, J K Ransom, K Adhikari and AF E Palmer (eds.).2002. Sustainable maize production systems for Nepal: Proceedings of a maize symposium held, December 3-5, 2001, Kathmandu, Nepal, NARC and CIMMYT.

Yadav NK. 2003. Status of Grain Legumes Research and Production in Nepal: Role of Legumes in Crop Diversification and Poverty Reduction in Asia. In: Proceedings of the Joint CLAN steering Committee Meeting 10-12 November 2003 ICRISAT-Patancheru, India, CLLGowda and S Pande (eds.) pp.102-114. 